ARTICLE

DOI: $10.1057 /$ s41599-018-0101-0

\title{
Populist communication in the new media environment: a cross-regional comparative perspective
}

\author{
Lone Sorensen (iD) ${ }^{1}$
}

\begin{abstract}
The changing terms of mediation place new demands, opportunities and risks on the performance of the political persona. Visibility has become a double-edged sword, leaving representatives vulnerable to exposure while new tools provide opportunities for emerging entrepreneurial actors. This double risk to elites' mediated personas-exposure and challenge from entrepreneurs-renders their armour of authenticity dangerously fragile, which nourishes a public sense of being inefficaciously represented. It is this climate in which populism currently flourishes around the globe. Three primary criteria of mediated selfrepresentation by politicians-visibility, authenticity and efficacy-form the focus of this paper: how do populists negotiate such demands in different democratic contexts, and wherein lies the symbiosis between populism and the new media environment suggested by the literature? To answer this, the paper compares two populist cases responding to different democratic contexts: UKIP, a right-wing party from an established democracy (UK), and the Economic Freedom Fighters (EFF), a left-wing party from a transitional democracy (South Africa). The objects of study are disruptive performances by these parties, which are considered emblematic manifestations of populist ideology as they establish a Manichaean relationship between the elite and populist actors who embody the people. The paper introduces disruption as a multi-faceted and significant analytical concept to explain the populist behaviour and strategies that underlie populist parties' responses to the demands for visibility, authenticity and efficacy that the new media environment places upon political representatives. Using mixed methods with an interpretive focus, the paper paints a rich picture of the contexts, meanings and means of construction of populist performances.
\end{abstract}

\footnotetext{
${ }^{1}$ School of Media and Communication, University of Leeds, Leeds, UK. Correspondence and requests for materials should be addressed to L.S. (email: L.N.Sorensen@leeds.ac.uk)
} 


\section{Introduction}

ape Town, 12 February 2015. A media event is in progress: photographers, prominent authorities and celebrity guests, designer dresses, swirls, photogenic smiles. But this year's State of the Nation Address (SONA) is not only keenly mediated for its pomp and ceremony. The reason why the nation is glued to their television screens, and why the SONA becomes South Africa's first real 'social media event' (du Plessis, 2015), is the promise of that most exciting form of politics: disruption, controversy, possibly (oh glee!) even violence, democracy being put to the test and disintegrating in real-time before the eyes of the nation.

Both the media's and the public's expectations are fulfilled. In a protest carefully designed to comply with parliamentary rules, MPs from the populist opposition party Economic Freedom Fighters (EFF) one by one rise 'on a point of order...in terms of rule $14 \mathrm{C}^{1}$ to question President Zuma on corruption charges. They succeed-not in gaining Zuma's admission of guilt but in exposing his SONA as a masquerade that is designed to hide the real state of the nation. An increasingly impatient and frustrated speaker eventually breaks parliamentary rules and orders armed police to forcefully evict the EFF from the House. This, also, is part of the EFF's performance which has carefully provoked the reaction of their authoritarian antagonists. Fist fights ensue to the delight, shock and awe of the tweeting broadcast audience.

At a remove of almost 10,000 miles and several centuries of democratic experience, the United Kingdom Independence Party (UKIP) fan the glowing embers of disenchantment with the European Union's grip on the sovereignty of the British people. They, also, disrupt the norms and rituals of a democratic institution: the European Parliament (EP). As military bands strike up and the EU flag is ceremoniously hoisted, UKIP dismiss the EP opening ceremony as 'nationalist', 'militarist' and democratically hollow, turning their backs to the playing of the anthem.

Then-leader Nigel Farage excels at increasingly gleeful and explicit breaches of the norms of political speech and behaviour as the Brexit referendum draws near, is won and makes the proverbial finger-sticking to the EU less proverbial. While UKIP's disruptions are more controlled than the EFF's colourful dramaconfined by the stringent norms and rules of the EP-Farage's repeated minor breaches of institutional norms provide continuous challenges to the establishment. Dripping with sarcasm, they succeed in provoking regular rebukes from the EP chair, reactions from the floor so indignant as to cause reprimands of their own, and establishing a counter-culture that seeps into UK mainstream politics.

UKIP and the EFF are performing their disruptive acts in a new media environment that reflects changes in the relationship between politics and the media. Despite the very different contexts of an established and a transitional democracy, the changing terms of mediation in many ways place similar demands, opportunities and risks on the performance of the political persona (Corner, 2003). Visibility has become a double-edged sword that makes representatives vulnerable to the constant dangers of scandal, gaffes, leaks and exposed outbursts (Thompson, 2005, p 41ff) while giving visibility entrepreneurs (Dayan, 2013) the opportunity to access power through new tools of visibility management.

It is this climate in which populism currently flourishes. Political representatives' difficulties in negotiating the demands on the visibility of their mediated political personas render their armour of authenticity dangerously fragile, which in turn nourishes a public sense of being inefficaciously represented. These three primary criteria of mediated self-representation by politicians-visibility, authenticity and efficacy (Coleman, 2011)form the focus of this paper: how do populists negotiate such demands in different democratic contexts, and wherein lies the symbiosis between populism and the new media environment suggested by the literature (see, e.g., Bos and Brants, 2014; Esser et al., 2016; Krämer, 2017; Mazzoleni et al., 2003; Moffitt, 2016; Stanyer, 2007, chap. 5)?

I argue that, while the UK's and South Africa's different pathways to democracy, political cultures and recent political developments lead the two parties to position themselves differently in relation to democratic institutions, both perform as visibility entrepreneurs, seeking to undermine the elite's fragile control of visibility through disruptive performance. In exposing the elite as impression managers, populists undermine the elite's authenticity and construct their own. Populists' incitement of distrust in politics is accompanied by a promise of efficacious representation which takes the form of identification with the people and the equation of authentic self-representation to truth telling. This problematizes the changing environment for mediated representation as it suggests that the emerging political communication landscape rewards illiberalism.

I develop this argument through the exploration of two populist case studies operating in very different democratic contexts, yet both marked by key changes to the environment of the mediation of politics: the radical-left opposition party the EFF in South Africa, and the right-wing opposition party UKIP in the UK. While I define populism as a thin-centred ideology according to Mudde's (2004) well-known definition, ${ }^{2}$ I am particularly concerned with how populist ideology manifests itself in the disruption of institutional norms and practices to thereby take advantage of the opportunities offered by the new media environment.

The remainder of the paper proceeds as follows. In the first section I discuss the concept of mediation and its relationship to populist communication and self-representation. I depart from previous scholarship on the mediation of populism by placing less emphasis on the institutional logic of this process. In this discussion, I draw on the concepts of visibility, authenticity and efficacy as an illustration of populism's symbiosis with the new media environment. In the second section I briefly outline the mixed methods and data sets that the study is based on. I then move on to an analysis of how the EFF and UKIP respond to each of the three challenges of visibility, authenticity and efficacy in their mediated self-representations. Finally, I discuss the implications to politics of populism's relationship to mediation in different democratic contexts.

\section{The mediation of populism}

The symbiosis between populist communication and the media has mainly been approached from an institutionalist perspective on mediation (Esser et al., 2016; Mazzoleni et al., 2003). This tradition of mediation research approaches media as independent social institutions with their own sets of norms and rules. Studies have focused on the affinity between a populist communication style and 'media logic' - the norms and routines that govern the media's operations (Altheide and Snow, 1979) — and have, for instance, identified specific news values such as conflict framing, strategic framing and personalisation that populism speaks to. The social constructivist tradition of mediation research beyond this institutionalist focus has been less explored in relation to populist political communication even though it provides a fertile avenue for investigating the mediation of populism in relation to media technologies and norms of use as well as institutions. Within the broader social constructivist tradition, the concept of mediation describes 'how communication has to be grasped as a process of mediating meaning construction' (Hepp and Krotz, 
2014, p 3) and is concerned with media's role in the communicative construction of socio-cultural reality. The term mediation then refers to a more substantive operation than the act of transmitting something through the media. Mediation is a problematic process concerned with the media's power to shape representations of 'reality' (Livingstone, 2009, p 5; Strömbäck, 2008, p 230), a process characterised by the media's substantive intervention to the extent that it affects and changes the object of mediation. This includes how political reality is depicted and understood.

Yet the social constructivist perspective allows us to understand mediation as a more complex process than the linear transmission suggested by approaches with an institutionalist focus (Couldry, 2008). Especially in the new media environment, both the flows and consequences of mediation are non-linear and multi-directional, to the extent that they involve a 'process of environmental transformation' (ibid. 2008, p 8). To paraphrase Livingstone's (2009) famous expression, everything is mediated. The mediated and the media mutually shape each other's conditions of production, understanding and use (Lievrouw, 2014) through a dialectic between a variety of actors, institutions and the environments that support them (Silverstone, 2005, p 189). With this complexity in mind, I follow Couldry in his definition of mediation as,

capturing a variety of dynamics within media flows... flows of production, flows of circulation, flows of interpretation or reception, and flows of recirculation as interpretations flow back into production or flow outwards into general social and cultural life. (2008, p 8)

The complex asymmetry and web of interconnections that this approach engages with is different in emphasis but nonetheless complementary to, and to some extent overlapping with, the institutionalist focus that is dominant in the populism literature. It allows us to examine not only the difficulties political actors face in their attempts to manage their mediated selfrepresentations by adapting to media logic. It also enables consideration of how certain actors have the potential to influence other actors and their mediated personas, how mediated representations travel and change within the media ecology, and the wider socio-political implications that result from the interplay between populist communication and the media in the hybrid media system (Chadwick, 2013). I am here particularly concerned with the way populists are able to make use of certain features of the new media environment to affect the mediated representation of the elite and to construct the environment in which they operate. Rather than focusing on the linear relationship between media institutions and populists, the adoption of Couldry's approach to the mediation of populism allows a more nuanced consideration of how populists and elites interact through processes of mediation, how they struggle over meaning and how they represent each other. This perspective can then be related directly to the political meaning constructed in populist ideology - the representation of the elite in opposition to the people and the consequent identification of populists themselves with the people-and the way in which it is communicated through mediated disruptive performance.

Further, this perspective suggests a spatial transformation and asymmetry as a consequence of changes in the media environment (Couldry, 2008, p 11-12). In the context of the mediation of populism, this in turn allows us to consider how populists use the symbolic action of disruptive performance in a variety of different functions and meanings that together constitute an expression of populist ideology whilst simultaneously transforming institutional spaces into effective sites for the mediation of their selfrepresentations. By challenging institutionally embedded norms and procedures, populists create new spaces for the flows of production, circulation, interpretation and recirculation of political symbols and meanings; and in doing so, they set the conditions for the elite's image management practices and suggest new epistemological conditions for the public's interpretation of politics. Coleman (2011) identifies three primary criteria of mediated representation that help us consider how political representatives tackle this new environment: visibility, authenticity and efficacy. In the following sections I discuss how these criteria intersect with populist ideology and communication practices.

Visibility. The requirement of visibility in mediated representation refers to how far representatives can be seen to represent us (ibid. 2011, p 47). Thompson describes how communication media have engendered a new form of visibility in which the field of vision is shaped 'by the distinctive properties of communication media, by a range of social and technical considerations (such as camera angles, editing processes and organisational interests and priorities) and by the new types of interaction that these media make possible' (2005, p 35-36). Dayan (2013) even argues that changes in the media environment have fostered a new paradigm of visibility. From the perspective of public representatives, these new affordances, practices and norms have undeniably changed the art of managing visibility (Thompson, 1995, chap. 4), providing opportunities for self-presentation, while the ubiquitous and multi-directional nature of mediation also makes visibility uncontrollable and public images inherently fragile.

The fragility to self-representation engendered by new forms of visibility can become a weapon in the hands of populists. The Manichaean element of populist ideology, which pitches the elite against the people, manifests itself in populists' attempts to undermine the public images of elite representatives. Politicians are well-known for their constant attempts at impression management-sometimes better than for their engagement in policy making - in response to the need for visible representation. Feeding into growing public discontent with, and distrust of, practices of impression management (Norris, 2001), coupled with the assumption that disclosure of discrete activities serves a democratic purpose, visibility has the potential to become not only a "weapon of the witness" (Coleman, 2011, p 46) as wielded by the media, but also a weapon of populists in their efforts to pitch the elite against the people.

The flows of production, circulation, interpretation and recirculation of symbolic content are even more difficult to control with the advent of social media. Political actors are forced to compete in shows of spectacle and drama against new non-elite actors who grasp the opportunity afforded by new media to become visibility entrepreneurs (Dayan, 2013). In Dayan's terms, visibility has become a right where withholding visibility is equated to "a silencing process" (ibid. 2013, p 150) by elites akin to 'old-school' authoritarian attempts at controlling communication media. The entry of such new actors into processes of mediation introduces an element of contestation over political symbols and meaning in online and physical spaces (Parry, 2015, $\mathrm{p}$ 423). These opportunities allow 'outsider' actors-such as populists-to not only acquire visibility but also to 'define the visibility of others, to become organisers of visibility' (Dayan, 2013, p 143). They may then impede on the terrain of journalists as the sole guardians of the holy grail of visibility. In conferring visibility upon the elite through disruptive acts of exposure, populists are able to provide the public with what Meyrowitz (1986, p 47) terms a 'sidestage' view, making visible the elite's act of managing their own visibility by displaying the discrepancy 
between their front- and backstage behaviour (Goffman, 1959), to expose the elite's professed authenticity as an act of deception.

Authenticity. In his classical work The Ethics of Authenticity, Taylor (1992, p 15-16) defines authenticity as a moral ideal of staying true to oneself (see also Trilling, 1972). As a result, perceived authenticity helps to build trust between politicians and the public (Pels, 2003). At the same time, it is continuously questioned and renegotiated. The prevalence of impression management in the mediated relationship between politicians and the public has resulted in the performance of authenticity being aimed at a process of mediation; it has 'become a strategy in its own right' (Enli, 2016, p 133). Yet citizens' analytical skills in deconstructing fake personas have also become more fine-tuned. While the media thirst for authentic politicians, they are therefore also equally inquisitive as to their constructed nature. Eager to expose backstage moments, they aid such deconstruction, with a dual motive of justifying their own contribution to the public sphere (Gurevitch et al., 2009, p 172-173; Louden and McCauliff, 2004) and surviving in a commercialised and competitive media environment. The result is to reinforce the decline in the public's trust of institutional politics (Catterberg and Moreno, 2006; Hay, 2013) since this trust is further damaged by a perception that 'everything in politics is designed for popular appeal' (Norris, 2001, p 168). Completing the cycle, authenticity then becomes a particularly coveted attribute in political self-representation (Coleman, 2005, p 194; Enli, 2016).

When considering authenticity in relation to the media and processes of mediation, we therefore become more concerned with the appearance of being authentic rather than with the moral ideal itself as it comes from within. Despite the seeming contradiction, authenticity, when aimed at a process of mediation, is a performed quality where the performer 'seems as though he or she is true to his or her inner self (Enli, 2015, p 111, my emphasis). Perceived authenticity by the public is therefore a mark of a successful performance (Alexander, 2011, p 54) in which the audience allow the characters onstage to merge with the actors who play them. A truly consistent and authentic political identity can only be achieved if the politician's public persona appears consistent with the private one; the performance of authenticity must never be seen to be performed. Managing visibility, and managing it well, so as to provide a consistent, spontaneous and intimate performance of authenticity (Enli, 2015, chap. 6) becomes so much more vital and so much more fraught with danger. Especially when populist disruptive characters are at play.

Populist ideology may then take the form of exposing elites as inauthentic and strategic performers, thereby rendering them inauthentic. A populist strategy of making visible the false authenticity performances by the elite feeds into a climate of public mistrust characterised by the precariousness of authenticity in mediated representation. But disruptive acts also serve to construct populists' own authenticity. In the words of Healey (2010, p 530), 'notions of authenticity... idealize the creative transgression of social norms'; that is, they idealise disruptive performance.

Efficacy. The struggles of public representatives to deal with the changing conditions of mediation through impression management have fed disenchantment with politics in the public to the extent that 'politics' has become a dirty word. As Hay argues, 'to attribute "political" motives is now invariably to question that actor's honesty, integrity or capacity to deliver an outcome that reflects anything other than his or her material self-interest' (Hay, 2013, p 1). The awareness of the deceit inherent in mediated representation and public communication therefore affects how people feel about politics and whether they feel properly represented (Bennett and Entman, 2001; Cappella and Jamieson, 1997). Efficacy is a subjective experience of how the represented perceive their own political agency to 'influence representatives to say and do the right things, or punish them if they don't' (Coleman, 2011, p 45). As such, it is based on a communicative relationship between representatives and the public (ibid.). Heightening feelings of efficacy would then rely on making such a relationship appear more meaningful, and possibly more direct, less mediated (or, at least, less problematically mediated).

The denunciation of processes and practices of mediationboth in relation to political institutions and to communicationis argued to be a central aspect of populism (see, e.g., De la Torre, 2014, p 18; Krämer, 2014; Kriesi, 2014). Populists seek to reinforce a sense that power runs directly from the people to themselves as representatives. They therefore evoke a gulf between elites and people over which this bond cannot stretch and demonstrate the closeness of their own connection to the people. Ironically, their condemnation of mediation within this claim fulfils one of the criteria of mediated representation, namely efficacy.

Internal efficacy-citizens' perceptions of their personal political competence and influence-has recently been connected to the access to information afforded by new media technologies (Coleman et al., 2008; Halpern et al., 2017). In a focus group study conducted in the Leeds area, Coleman et al. (2008) further report that most participants perceived such technologies to establish a more direct link to their representatives. Participants articulated a sense of estrangement from the political world, which often resided in official language, uniformly referred to as 'political correctness' (ibid., p 779). In this sense, a populist communication style, characterised by 'ordinariness' and 'bad manners' (Moffitt, 2016, p 44-45) may serve to increase internal efficacy, especially when such a style remains intact in the process of mediation, for instance through social media.

Meanwhile, Coleman et al.'s study suggests that external efficacy-the perceived responsiveness of representatives-is decreased by the perception that representatives will only initiate an interactive relationship with the public for the purpose of garnering votes during election campaigns (2008, p 780-781). Such relationships can often be characterised by a lack of understanding of common everyday life and by practices of deception (ibid. 2008, p 782). Populist acts of disruption aimed at undermining efficacious representation by the elite through the exposure of such practices of deception can consequently be seen as a direct manifestation of populist ideology.

\section{Method}

This study adopted a comparative case study design combined with a mixed methods approach to explore how populists use disruptive performances to negotiate changes to the conditions of visibility, authenticity and efficacy of mediated representation in different democratic contexts. Whilst comparing two parties situated in the similar overall liberal-democratic contexts of the UK and South Africa, the cases display clear contrasts in the more specific elements of their historical and socio-political conditions. The case study approach allows a multidimensional, thick description of the cases as situated in their respective contexts, while the comparative design enables the drawing of parallels and contrasts between the two distinctive, multidimensional contexts. Socio-political conditions, such as party status (opposition), regime type (dominant-party rule versus established representative democracy), path of democratic transition (bottom-up liberation and current backwards trajectory with weak institutions 


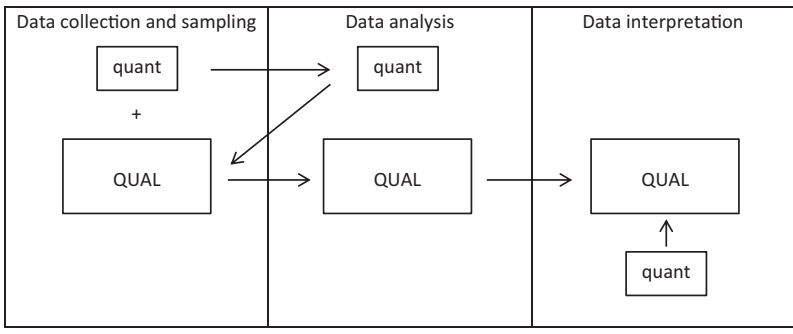

Figure 1 Mixed methods research design

versus stable, established and strong institutions) and mode of representation (descriptive mode with lack of responsiveness versus active mode with lack of identification) were influential in my choice of case studies. While these conditions constrain and enable the two parties' disruptive performances, institutional norms form a yardstick for discursive practice, for instance in the form of rituals that seek to confine disruption by making norms incontestable. Disruptive performances seek to violently overturn established norms and construct a 'new normal'. While material conditions thus constitute the framework of the research design, my concern is with how populists portray this reality, and change it in the process of doing so.

To investigate this I used a mixed methods concurrent nested design (Creswell et al., 2003, p 229-230). I gave priority to qualitative research, primarily using the quantitative element for purposes of zoom-in sampling of Twitter data for interpretive analysis (Gerbaudo, 2016). I further integrated a descriptive quantitative analysis at the interpretation stage of research for purposes of triangulation, contextualisation and enrichment, placing the populist disruptive performances in a broader mediated context (see Figure 1).

The data used for this paper are part of a larger study that relies on a broad range of communicative outputs-conceived as elements of performance in both live, digital and otherwise mediated forms-by UKIP and the EFF that map a total of six disruptive performances in the South African and European parliaments between July 2014 and April 2017: video footage and official transcripts of live performances in parliamentary settings, press releases, tweets, media appearances, newspaper columns and promotional YouTube videos. I supplemented these communications by the two populist parties during their disruptive performances with media coverage of the events and public conversations on Twitter about the events. I selected the sampling periods and thereby also defined the duration of the events based on when the given populist party initiated and ended their own communications about the event. Together the data sets of direct populist communications and their mediated manifestations provide a multi-dimensional, rich picture of the immediate context of each disruption: the main actors' justification for and legitimisation of the disruption, media coverage of the disruption, and the immediate public reaction to the disruption. ${ }^{3}$

The Twitter data formed the quantitative element of the mixed methods design and was collected concurrently with the remaining data. For the quantitative sample, I iteratively identified hashtags and keywords related to the given event and used the open source tool Mecodify ${ }^{4}$ to scrape and visualise historical data from Twitter. Initially the quantitative data set formed the basis of a descriptive analysis that reconstructed the events, visually mapping online public activity to offline events and media coverage in a normalised histogram. I then I went beyond the approach of data analytics often adopted in big data studies and gave priority to a data hermeneutics approach (Gerbaudo, 2016). For this purpose I used the same tool to conduct zoom-in sampling during peaks of activity and/or significant moments of a live disruption. These smaller data samples of the Twitter public's reaction to offline events supplemented my primary data of communications in various media and modes initiated by the two populist parties during the events.

For the interpretive analysis of populist communications I inductively coded all data relying on a grounded theory-based analytical approach (Charmaz, 2006). In the analysis of populist performance, I paid particular attention to the construction of binaries (Van Dijk, 2016) and chains of equivalence (Carpentier and De Cleen, 2007; Phillips and Jørgensen, 2002) to assess how the populist parties constructed reality in different media. In particular, I considered how populist disruptive performances sought to manage their own and the elite's visibility, how they constructed authenticity and rendered the elite inauthentic, and how they sought to engender efficacy through the interplay between their communication style, ideology and media use.

I define the objects of analysis-disruptive performances in parliamentary institutional contexts-'literally as a disruption of parliamentary business and procedure, and figuratively as a disruption of the norms embedded within the ritual of parliamentary debate' (Spary, 2010, p 338). In the context of populism, I conceive of disruptive performance by populist actors as an especially emblematic manifestation of populist ideology that is geared towards processes of mediation: a challenge to mainstream politics that pitches the elite against the people through an explicit and spectacular struggle over democratic norms and procedures and that speaks to the conditions of the new media environment. Disruptive performances are therefore a rich source of data on populist self-representation in relation to mediated events.

According to Goffman (1959), performance is an embodied activity that influences its observers. Such activity displays meaning that the actor(s) wish to have their audience believe (Alexander, 2004, p 530). An effective performance must be plausible and lead 'those to whom their actions and gestures are directed to accept their motives and explanations as a reasonable account' (ibid.). This notion of performance relates to Austin's (1975) concept of performativity whereby certain types of speech acts-which we may here extend to symbolic acts more generally (see, e.g., Alexander, 2006) as the objects of study in questionhave the ability to realise their semantic contents. That is, they construct reality. Austin suggested that the evaluative standard of such performatives be 'felicity,' as opposed to truth or accuracy, since the latter do not necessarily denote whether performatives work successfully.

According to Alexander (2006) ritual is the ultimate successful performance since their status is unquestionable and their character is perceived as being authentic. Populist disruptions of political rituals can therefore be seen as attempts to undermine their felicity by exposing the reality that they construct as just that, constructed. The performative struggle between elite ritual and populist disruption is a struggle that seeks to deploy the weapon of visibility to undermine the authenticity of the opposing party's act and, ultimately, their efficacy. The data used for this study therefore seek to map this site of struggle in a rich picture of how populist actors construct political meaning in response to elites.

\section{The struggle over mediation: the self-representation of UKIP and the EFF and the criteria of mediated representation}

Populists are famously antagonistic towards mainstream media whom they perceive as part of the elite. UKIP state in a tweet, 'our media are guilty of double standards', ${ }^{5}$ while the EFF complain of 'sustained media attacks... with the sole aim of casting aspersions on [our] leadership and the organisation as a whole'. ${ }^{6}$ The 
demands on mediated representation for visibility, authenticity and efficacy can therefore be expected to grate with populists. But do they? I explore populist self-representation in relation to the three criteria of visibility, authenticity and efficacy in the following three sections. In each section I investigate UKIP's and the EFF's reproof of the elite's pandering to the media, the parties' own self-representations in relation to the media, and their performative orientations towards the media's demands for visibility, authenticity and efficacy, despite their seemingly antagonistic relationship. In doing so I distinguish between the populist claims at face value and the way in which they are constructed and performed through disruption with a view to their mediation.

The weapon of visibility. The unquestionable status of political rituals as successful performances make them natural sites of performative and discursive struggle over the management of visibility. In both UKIP's and the EFF's disruptive performances, institutional rituals are portrayed as masquerades that undermine the democratic function of parliament: 'Parliament which is supposed to fight corruption by holding the executive accountable has been turned into a fashion parade, ${ }^{\prime}$ tweet the EFF in their report of the SONA media event. The EFF refuse to conform to the formalities of the elaborately staged ceremony, remaining sitting when all others stand during the president's arrival. Describing it as 'that state of the nonsense', ${ }^{8}$ they point to the meaninglessness of the staged ritual and its discrepancy with the reality of South African politics: 'When you are telling a so-called good story here, the children of Sxwetla sleep side by side with rats....'. The EFF thus engage in disruption through an assemblage of live symbolic action, tweets and other direct communications to provide a sidestage view of the elite's performance of ritual as a visibility management practice.

Like the EFF, UKIP seek to expose European Parliamentary norms and rituals as staged visibility events that are detrimental to democratic representation. At the EP's opening ceremony, then-deputy leader Paul Nuttall points out the emptiness of its 'faux nationalis $[\mathrm{t}]^{10}$ symbols as antithetical to 'proper representation': 'We stand up for our people, not the EU flag and anthem.. ${ }^{11}$ Nuttall defuses the symbolic value of the EP's ritual and portrays it as directly detrimental to 'our people' and as self-serving: the ritual is not a means of democratic representation but a staged spectacle designed to manage and control visibility. UKIP then perform a silent protest of turning their backs to the playing of the EU anthem, uncannily echoing the EFF's refusal to stand for President Zuma.

Both parties thus engage in symbolic acts aimed at exposing the constructed and empty nature of elite rituals. They deny any practices of visibility management themselves, which they even portray as incompatible with principled democratic practice - 'We shouldn't chase headlines. We must stick to the principle', tweet the EFF. ${ }^{12}$ Farage likewise points out the unscripted nature of UKIP's political communication practices: 'the people's army has not been carefully engineered by an imaginative press office.'. ${ }^{13}$ Yet both parties' disruptions are designed and staged with visibility in mind. The EFF's orchestration of their major disruption is elaborate. They promise drama through an entrepreneurial use of Twitter in the lead-up to the event. EFF leader Malema for instance tweets, 'For the first time in the history of the South Africa, something is going to happen in the \#SONA'. ${ }^{14}$ Continuing to build up tension, he posts an image of a smug-looking Zuma with the incendiary caption 'We are ready for u boy'. ${ }^{15}$

The EFF's threat to define the visibility of the South African elite serves to manage their own visibility by creating media coverage. But it also increases the elite's anxiety over their threatened visibility to the extent that they prepare to-and dotransgress liberal democratic practice in a last-ditch attempt at control. The government blocks the mobile telephone signal in the parliamentary chamber to prevent journalists from using the affordances of internet-based media to report on the expected disruption, and it bans the public broadcaster SABC from showing the ruckus of the EFF's expulsion from the House in an attempt to control the mediated reality. Meanwhile the hashtags \#SONA and \#SONA2015 experience an unprecedented peak on Twitter of 348,755 tweets ${ }^{16}$ for a South African political event. In this medium, the EFF take up the fight over mediated reality: 'SABC has been instructed not to show EFF MPs', ${ }^{17}$ they tweet. The EFF proceed to usurp the role of the public broadcaster, using the style of tweeting that Larsson in his typology denotes Twitter's broadcasting function (2015). They live-tweet reports of events every few minutes and convey in graphic and visual detail all the to-do not shown by the SABC to a rapt national audience. The EFF succeed in performatively constructing a reality where they are the conveyors of truth, the government the unsuccessful authoritarian censors.

UKIP also make entrepreneurial use of the new media environment in ways that build up and complement live disruptions aimed at broadcast audiences. Farage takes to Twitter to warn that 'Sparks will fly ${ }^{18}$ in a build-up of tension before his provocative EP speech on the UK's triggering of Article 50 that commenced her exit from the EU. As Farage is about to start the speech, he glances directly up at the camera, catching its eye and betraying his awareness of the wider broadcast audience that he may garner with his disruptive performance. UKIP follow up live events on social media, for instance posting a disdainful YouTube video $^{19}$ of an EP opening ceremony, featuring Farage in a supposedly backstage moment having a conversation with a fellow MEP in which he equates the EP ritual to the nationalist militarism of Nazism. This supposedly private-conversationmade-public is portrayed as fully consistent with Farage's frontstage behaviour, resonating with arguments he puts directly to the EP and in public newspaper columns. It thus implicitly contrasts UKIP's own performances with the inconsistencies between front and backstage behaviour that the elite exhibit in their attempts to manage visibility.

Disruption as a source of authenticity. In a climate where new weapons of visibility make self-representations increasingly fragile, authenticity becomes a prized possession. Consistently with populist ideology, the authenticity of the elite becomes a prime target for populists. Both UKIP and the EFF accuse the elite of scripted performance: 'Zuma... must not read to us. We're not in Sunday school'. ${ }^{20}$ The exposure of elite performance as unspontaneous, calculated and aimed at mediation engenders mistrust of the elite's intentions, a suspicion of inconstancy and fabrication in their mediated front, and prevents intimacy with the public. The EFF repeatedly expose the ANC's calculated rhetoric, such as their 'hollow recitals of the Freedom Charter...that are not genuine'. ${ }^{21}$ In fact, the EFF claim, the ANC's programme is wholly inconsistent with the Freedom Charter, and 'any talk of the Freedom Charter is meant to mislead the people of South Africa $^{122}$ (my emphasis). In South African politics, such false, empty evocation of the Freedom Charter equates to democratic blasphemy, a betrayal of the ideas underlying the struggle for independence, which in turn is a betrayal of the people and their liberty.

UKIP likewise expose the constructed nature of the elite's authenticity. Farage accuses his fellow MEPs of expressing 'faux outrage', 'hyperbole' and 'hysteria ${ }^{123}$ in a debate about President Trump's new immigration measures. The elite's apparent moral 
indignation is staged for the media in a false performance of authenticity, he claims, and proof lies in the inconsistency between the elite's 'rhetoric' and their previous actions and positions on related issues:

...where were you when Obama, in 2011, banned any Iraqi from going into the country for six months? Why do I hear no criticism in this chamber or from the Commission of Saudi Arabia, Kuwait, Bahrain and others who have refused to take a single, not one, refugee or displaced person from Syria? ${ }^{24}$

He exposes the elite's rhetoric as an attempt to hide their extremist world view-their 'anti-democratic zealot $[\text { ry }]^{25}-$ behind an empty performance for the cameras.

For their own part, UKIP's message is portrayed as sincere and consistent with its values: UKIP MEPs claim to be 'a team who believe in what they say', not changing their 'accents and grit ${ }^{26}$ for the sake of impressing the media. The EFF express comparable sincerity and genuine belief in their 'radical and militant programme' which they 'unapologetically pursue'. ${ }^{27}$ Like UKIP, they legitimise this belief with its 'true resonance with the people of South Africa' ${ }^{28}$ and their own identification with the people. Both parties' authenticity is proven by the consistency between their frontstage and their backstage behaviour.

The two parties not only state their claims to consistent and authentic personas. They also generate these claims performatively. Their acts of disruption have an inherently spontaneous quality, for staged spontaneity can at times seem more spontaneous than 'real' spontaneity (Enli, 2015, p 10; see also Goffman, 1959, p 8-9). Such spontaneity suggests that the breaking of norms is a worthwhile sacrifice to express oneself in accordance with one's true self (Enli, 2015, p 10; Healey, 2010, p 530), that is, to be authentic. The two populist parties even go one step further in generating authentic self-representation through disruptive performance. They use the new media environment to redefine authenticity, equating it to truth telling. Farage makes a point of paying homage to the 'institution of truth', ${ }^{29}$ not the norms of the institution of the Commission, when he is reprimanded by the EP chair for breaking the norms of acceptable political speech. Afterwards he takes to Twitter to further associate his disruptive act with truth telling: 'Just gave both barrels to the unelected EU commission. These guys have a problem with the truth'. ${ }^{30}$ This self-representation as truth teller in contrast with the falsity of the elite is echoed by the EFF who portray themselves as 'an organisation that always tells the truth and claims no easy victories'. ${ }^{31}$

Both parties claim to serve a democratic function through their acts of disruption since the people would be unable to see the truth were it not for their intervention. Farage tweets, 'If I've helped the British people understand how ridiculous the EU are behaving, I couldn't give a damn who I upset'. ${ }^{32}$ The EFF likewise portray themselves as saviours of a misguided people when they criticise the elite for 'playing with South Africans'. ${ }^{33}$ They even go so far as to attack the people for living with a lie and not wanting to face up to the truth:

Parliament continue to violate the constitution. And every South African is happy, every South African is celebrating that and condemning those who are saying this is wrong. Those who are saying this is wrong get condemned, they're disruptive, they're disrespectful, you're so comfortable to live with a lie, you're so scared of the truth! ${ }^{34}$

But in doings so, the EFF refuse to lay claim to the accusation of disruption, a term that, in the South African context, carries negative connotations as it suggests damage to fragile democratic institutions.
The different democratic conditions faced by the two parties suggest different expressions of relations between populist actors and people. UKIP adopt the role of helping a silent majority realise their own lack of voice in a heavily formalised and inflexible institutional setting that allows limited room for manoeuvre outside of stifling and self-perpetuating norms. According to UKIP's claim, compliance with the norms of political speech prevents the expression of true belief, making disruption a democratic necessity. In the context of the strictly norm- and rule-bound conditions of the European Parliament, however, making this symbolic point only requires-and allowsminor transgressions of norms. The EFF's role as truth tellers is more urgent and demands a 'radical and militant ${ }^{\prime 35}$ approach to break through the severe conditions of the elite's authoritarian practices of deception and repression. The EFF can then claim that their act of disruption is a question of morality, of doing 'their constitutional duty... to defend and stand for what is right. ${ }^{36}$ (my emphasis). In both cases, the parties self-represent as prophets of truth and democratic saviours. They are not one amongst a choice of parties on an ideological spectrum but the only voice of truth and the only possibility of saving the people from suppression and deception. They obtain the legitimacy of this role through the performance of authenticity where they make use of complex and interrelated flows of mediation in a hybrid media environment.

Symbolic embodiment as efficacious representation. UKIP's and the EFF's portrayal of the elite rests on a notion of politics as incestuous and self-interested, characterised by 'stitch-ups, slanderous accusations, voters' wishes ignored'. ${ }^{37}$ Their own selfrepresentation as efficacious representatives builds on their closeness to the people. They make this claim both explicitly and performatively with resort to the new media environment. In the case of UKIP, the elite's distance from the people is an institutional problem; the EU is 'stuck in its own lavish bubble detached from reality'. ${ }^{38}$ UKIP's central claim is that the institution of the EU takes precedence over the people in a manner entirely antithetical to what democracy ought to be: 'The EU are putting the interests of their failed project above that of their own citizens'. ${ }^{39}$

UKIP link this culture of self-obsessive, inefficacious 'big politics $^{140}$ to the institution of the EU itself. The elite render their institution dysfunctional by an obsession with their own internal squabbles while the people are forgotten, yet they are self-serving in a collective sense, joining forces only to support the misguided and nonsensical goal of the EU for the EU's sake. Instead of representing the people, the EU has become a bureaucratic and self-sustaining eternity machine that traps and confines the people, prompting UKIP to 'work for the freedom of people from EU legislation and waste'. ${ }^{41}$ ot only does UKIP equate the European rule of law to waste; they also directly oppose it to a vague notion of 'freedom', arguing that it removes representatives from the people. In this sense the $\mathrm{EU}$ is an institution that (unnecessarily) mediates the relationship between the people and their national representatives and, in doing so, weakens efficacy.

The EFF share UKIP's view that the elite's non-efficacious representation has lost sight of the purpose of democracy. But in the EFF's case, the new post-Apartheid black elite are portrayed as traitors of their own people, enriching themselves through positions of power: 'we know... that the ANC will never nationalise Mines [as stated in the Freedom Charter] because majority of its senior leaders are benefitting from privately owned Mines'. ${ }^{42}$ The corrupt behaviour of the elite subverts the democratic culture of the institution of parliament, which the EFF perceive as distinct from the elite who undermine it: 'Parliament...must be respected as sacrosanct'. ${ }^{43}$ In this view, the 
elite are authoritarians who by definition do not fulfil the people's wishes. To underline this argument, the EFF evoke South Africa's colonial past: 'Don't be intimidating. We finished that', ${ }^{44}$ an EFF MP protests as he likens the speaker's attempt at quelling his interruption to Apartheid-like oppression.

Both parties then view elite politics as immoral, undemocratic and inefficacious. But whereas UKIP point to the institutions of the EU as problematic in and of themselves, the EFF champion them as means of achieving efficacy. In the EFF's case, the elite's lack of efficacy therefore resides in their self-interest, maintained through authoritarian practices rather than through institutional bureaucracy. UKIP can rely on institutional fatigue in a context of established democracy. The EFF, in contrast, face conditions in which the institutions of democracy are seen as sacrosanct, expensively attained in living memory by the people themselves through bottom-up protest. The EFF therefore signify the South African elite's distance from the people through their likeness to the Apartheid regime. In both cases, however, the very act of representing the elite as self-serving and unconcerned with the interests of the people engenders inefficacy: it makes people feel their voices go unheard in the political process. In this sense, the inefficacy of the elite is to a large extent a populist construction, even if it requires a firm foundation in recognisable reality.

In order to achieve the unproblematic mediation of this version of reality, both parties engage in entrepreneurial communication practices. First, they rely on modes of mediation that avoid interfering media institutions and editorialising. Farage's communications pivot on his own LBC radio talk show, regular newspaper columns and tweets, while Malema and the EFF are avid tweeters and hold regular live rallies. Such direct forms of communication enable the untainted mediation of 'ordinary', informal styles that signal a direct connection to the people, such as Malema's frequent use of slang-'Take a chill pill. Don't be tjatjarag ${ }^{45},{ }^{46}$ - which is so well suited to the norms of social media.

Second, both parties rely on simple visual imagery to be conveyed through traditional mass media as clear symbolic acts. Dressed uniformly as domestic workers in bright red overalls, EFF MPs symbolically identify with ordinary South Africans through a homogenous representation of the people and stand out from the mass of grey suits of the mainstream elite in parliament as firstclass camera fodder. Like UKIP, they claim to have resonance with the people based on performative identification. Farage achieves a similar effect by frequently donning a pint of beer in photoshoots, displaying a Union Jack on his desk in the EP, and spouting provocations that at once create selling headlines and epitomise the notion of political incorrectness as a sign of closeness to the people and exposure of the populist's private persona.

UKIP portray their wilful transgressions of the norms of institutional behaviour and political speech as proof of their own efficacy: 'UKIP has not gone to Brussels and Strasbourg to be placid and inert. We made a promise to you to fight for what you believe in. And that is what we are going to do'. ${ }^{47}$ While UKIP promote disintermediation in the form of the eradication of the EU as what they perceive as a mediating institution, they adopt the same approach in relation to the media. Through frequent use of the hashtag \#PeoplesArmy on Twitter, for instance, they at once engender efficacy through the suggestion that they are a force directed by the people, bypass the mediating institutions of mainstream media, and signal a more direct relationship to the people through Twitter's 'direct' affordances with the use of a hashtag.

\section{Discussion}

In the preceding pages I have outlined how UKIP and the EFF respond to changes in a media environment characterised by complex, multi-directional and often uncontrollable flows of production, circulation, interpretation and recirculation of political meaning. The fragility of public representatives' selfrepresentation in this new media environment becomes a weapon in the hands of populists. They expose elites to new forms of visibility in entrepreneurial ways, thereby undermining the elite's authenticity and engendering inefficacy in their representation. Emergent forms of visibility, authenticity and efficacy in populists' own self-representation combine with populist ideology, which pitches the elite against a homogenous people. They manifest themselves in populists' exposure of one particular aspect of mainstream politicians' behaviour that elites would wish to keep invisible: the constructed nature of their visible performance.

Despite denying that they adapt their practices to the media, both UKIP and the EFF engage in disruption of political norms that catches the media's attention and lends them control of both their own and the elite's visibility. The two populist cases thus address the challenges of the paradigm of visibility through entrepreneurial forms of meta-performance, designing their own performances to expose the crafted and crafty nature of elite visibility management. To populists, visibility is not a threat; it is a weapon. They turn the sharp side of Thompson's proverbial double-edged sword against the elite in a show that captures both digital and traditional audiences. Their disruptive performance pivots on their dismissal of any pandering to the media as undemocratic whilst simultaneously showcasing their imperfections through a mosaic of mediated forms. Indeed, their 'grit', their norm breaking and their ordinariness become emblems of their authenticity and badges of their merit as representatives. The fragility bestowed upon representatives by new forms of visibility becomes a celebrated occasion for populists to wash their dirty linen in public - and that of the elite. Populist disruption is then an act with two felicitous outcomes: it forces increased visibility on and exposure of elite falsehoods and practices of impression management; and it manages populists' own visibility in a volatile mediation environment.

Populists' public performances of supposedly backstage behaviour free them from the demands of consistent selfrepresentation that have become near-impossible to fulfil in the new media environment. For a politician to be authentic, their front- and backstage behaviour must be consistent. Both UKIP and the EFF relish the exposure of such inconsistencies in the elite, thereby providing the public with a 'sidestage' view (Meyrowitz, 1986, p 48) that lays bare the constructed nature of mainstream politicians' performances and renders them inauthentic. In doing so, they usurp the role of the media as the fourth estate. The internal logic of the populist claim then builds on the portrayal of populists' authenticity as a matter of morality. In the evocation of authenticity as a moral ideal, populists echo Taylor's (1992) account of authenticity. However, in the populist case, their claim to morality manifests itself in the equation of performed authenticity with truth. Such equivalence is founded on a particular evaluation of elite performance, which gives rise to populists' own representation as truth tellers and to an essentialism that amounts to illiberalism.

The reassurance of truth, coupled with embodied identification with the people, allow the two parties to engender feelings of efficacy in the public. These feelings are further reinforced by the parties' use of social media as a form of symbolic action that signals that power runs directly from the people to their populist representatives. While the two parties share this behaviour, their different democratic contexts give rise to different positions on the role of democratic institutions. The EFF's championing of the institution of parliament 
contradicts positions in the literature that hold that populists always favour disintermediation (see, e.g., De la Torre, 2014; Kriesi, 2014). Given the Manichaean element of populist ideology, the illiberal and illegitimate practices and actions of the South African elite invite the EFF to self-represent as upholders of certain principles of liberal democracy. As a consequence, they support democratic institutions, stand up against corruption and demand increased responsiveness of representatives to the people. Yet they flaunt the norms of liberal democracy and subscribe to a moral essentialism similar to UKIP's, which resides in the common self-representation as 'unperforming' and authentic truth tellers. Although the EFF's form of populist representation indeed seeks 'its unity in the embodiment of the people' as De la Torre holds (2014, p 18), the South African case suggests that democratic institutions themselves can be imbued with a similar symbolic meaning to complement such symbolic embodiment. The institutions themselves then become emblems of victory for the silent majority.

In the preceding pages, the concept of disruptive performance has emerged as a significant dimension of a populist communication style, and one with multiple facets. Disruption takes a variety of forms: disruption of the norms of political speech, of accepted political behaviour and of the performances of other political actors. It further encompasses a range of signifying practices as populist actors engage in symbolic action that stakes a claim to: expose the falsity of conventional norms and procedures of mediated representative politics, identify with a particular notion of 'the people', and express populists' ideology in pure, unadulterated form. As such, disruption is a key means of manifesting populist ideology in a way that simultaneously garners attention across the media ecology. In doing so, the concept of disruption underlies the criteria of mediated representation: it serves to control the visibility of the elite and of populists themselves, it signals authenticity, and it provides proof of and engenders efficacy. It thereby proves itself a multi-faceted and significant concept that should be made more explicitly involved in future research on populism.

Populists' disruptive response to the new media environment has several implications, and I will draw out two of the most important ones in conclusion. First, UKIP and the EFF's exposure of the elite's duplicitous and even undemocratic practices plays an important democratic function, especially in the South African context of a transitional democracy. Indeed, both parties found their self-representations on a wish for a more substantive politics, a politics in which representatives have the people's true interests at heart rather than simply going through the motions of the procedures of liberal democracy, like garnering votes and winning elections. These procedures, they claim, are undertaken by elites as means of duping the people into believing that their rhetoric and masquerades are genuine expressions of democracy when in fact they merely hide the elite's self-serving ends. The populist parties condemn both the media and the elite for losing sight of the substance of representation: in their obsession over image, they forget the people they both claim to serve. Populists claim to, in contrast, have a moral quality that set them apart and enable them to provide a more substantive mode of representation. They have an inherent understanding of the people-even embody them-which they demonstrate through the performance of authenticity.

Yet when performed authenticity becomes a moral necessity, the populist parties allow it to trump social and political norms and to legitimise the breaking of norms through disruptive behaviour. A strong theoretical argument is emerging (Azari and Smith, 2012), supported by empirical indications in the wake of Trump's presidency (Nyhan, 2017), that political norms are essential for a more substantive form of democracy. More problematic aspects of norm breaking can legitimise the 'ugly extremes of social exclusivism, such as nationalism, racism, and sexism (Eriksen, 2002; Lieberman and Kirk, 2004)' (Enli, 2015, p 11). This is indeed often an effect of populism, as many empirical studies corroborate. Thus, despite a populist call for increased substantiveness in democracy, the deprioritisation of norms has a potential to lead to reliance only on procedure and institutionalised rules and legal frameworks in practice. This in turn ironically reduces substantiveness, especially with respect to communication between citizens and representatives (Blumler and Coleman, 2015), which in turn erodes the promise of responsiveness.

A second implication follows from the populist claim to the status of truth tellers: the assumed need of the people to be freed from the elite's veil of false consciousness. In the populist claim, the act of disruption is undertaken in order to enable the misguided people to see through the lies of the elite, to finally become cognizant of the 'reality' that hides behind the masquerade of 'politics'. This suggests that populists question Austin's (1975) adoption of felicity as a condition of evaluating performatives, as opposed to truth. In the populist claim, felicity is normatively problematic; it is an indication of the level of deception that politicians have achieved over the people. The more felicitous the performative, the more undemocratic the behaviour of the performing elite.

Instead populists apply the criterion of truth to the performance of ritual as a democratic practice, which in turn aids an epistemological shift towards essentialism. The implication here is that the essentialism inherent in the populist performance allows no acknowledgement of politicians' need to concern themselves with image, style or differentiated audiences in the modern political communication environment. To populist eyes, all such inconsistencies are signs of what Meyrowitz characterises as 'unscrupulous politicians who have no true commitment to their own performances' (1986, p 279). As a result, in the populist claim the only morally acceptable way for public representatives to meet the challenges of the new media environment is to perform a politics of morality. It is a circular argument that replaces political value systems with morality and truth as guiding lines in democratic practice. This in turn creates an essentialist politics as a divide between us and them. The implied lack of pluralism grows directly out of the heady cocktail of populist ideology and new forms of visibility, authenticity and efficacy that are suited to the new media environment.

Received: 12 January 2018 Accepted: 20 March 2018 Published online: 24 April 2018

\section{Notes}

1 2015/02/12. State of the Nation Address, Cape Town, South Africa. Footage available at: https://www.youtube.com/watch? $\mathrm{v}=\mathrm{i} 24 \mathrm{~L}$ coQ9Tus and https://www.youtube.com/ watch? $=$ gPluIw3uPPo (Accessed 3 Feb 2017). Hansard transcript available at: http://www.politicsweb.co.za/documents/signal-jamming-and-eff-expulsion-at-sonafull-tran (Accessed 3 Feb 2017)

2 Mudde defines populism as 'an ideology that considers society to be ultimately separated into two homogeneous and antagonistic groups, "the pure people" versus "the corrupt elite", and which argues that politics should be an expression of the volonté générale (general will) of the people' (2004, p 543). Mudde’s minimal definition lends itself to the comparative study of different types of populism (see Mudde and Rovira Kaltwasser, 2012, for this argument in detail), such as those of the EFF and UKIP. An ideological definition-rather than, for instance, a stylistic (see, e.g., Moffitt, 2016; Jägers and Walgrave, 2007) or discursive (see, e.g., Aslanidis, 2016; Hawkins, 2010; Stavrakakis et al., 2016) approach-furthermore enables such a 
comparative study to encompass the different styles of populist communication found in different political cultures and expressed through different media. For a more detailed discussion of the question of how populist ideology manifests itself in a communicative style and performance, see Sorensen (2017).

3 When citing primary data, I do not identify incorrect grammar or spelling with 'sic' since it would be too distracting given the extent of such errors.

4 Using Mecodify's web search method for data collection produces results that mirror those that emerge using a web search through Twitter's Advanced Search page (https://twitter.com/search-advanced). According to Twitter's own documentation, this method behaves similarly to, but not exactly like, Twitter's Search API. Hence, there is no guarantee that all tweets will be returned. However, it has been demonstrated through extensive testing that the search results obtained through Mecodify do match those returned through Twitter's search form.

5 2017/01/30. Tweet ID: 8.26078191529897E+17.

6 2015/01/25. 'EFF statement about misleading newspaper and social media reports: statement by the secretary general'. Available at: https://web.archive.org/web/ 20160415101933/http://effighters.org.za (Accessed 23 June 2017).

7 2015/02/13. Tweet ID: 5.66180022189559E+17.

8 2015/02/13. Tweet ID: $5.66195460394979 \mathrm{E}+17$.

9 2015/02/17. 'The EFF statement on disciplinary action against Mngxitama and Tshabalala'. Available at: https://web.archive.org/web/20160415101933/http:// effighters.org.za (Accessed 23 June 2017).

10 Arnott, J. 2014/07/03. 'Stitch-Ups, Backstabbing and Voters Ignored-24h in the European Parliament'. Huffington Post. Available at: http://www.huffingtonpost.co. uk/jonathan-arnott/european-parliament_b_5553939.html (Accessed 23 June 2017).

11 2014/07/01. Tweet ID: 4.83923040041205E+17.

12 2015/01/13. Tweet ID: 5.54957511452033E+17.

13 Farage, N. 2014/07/04. 'Farage on Friday: UKIP hasn't gone to Brussels to be placid and inert' vows Nigel Farage'. Daily Express. Available at: http://www.express.co.uk/ news/uk/486838/Ukip-leader-Nigel-Farage-on-EU-Parliament-Brussels (Accessed 23 June 2017).

14 2015/01/13. Tweet ID: $5.54951206972719 \mathrm{E}+17$.

15 2015/01/25. Tweet ID: $5.59348 \mathrm{E}+17$.

16 Volume of tweets, including retweets, on the day of the SONA, 12 February 2015

17 2012/02/12. Tweet ID: $5.6592 \mathrm{E}+17$.

18 2014/04/04. Tweet ID: 8.49363012448391E+17.

19 UKIP MEPs. 2014/06/30. 'Naked EU Militarism on Parade - with short comment from Nigel Farage'. Available at: https://www.youtube.com/watch?v=lDyoAAJlmbw (Accessed 23 June 2017).

20 2012/02/12. Tweet ID: $5.65775 \mathrm{E}+17$.

21 2015/01/10. 'The EFF statement on the hollow recitals of the freedom charter by the ANC'. Available at: https://web.archive.org/web/20160415101933/http://effighters. org.za (Accessed 23 June 2017).

22 Ibid.

23 2017/02/01. European Parliament debate on travel restrictions following US President executive orders. Footage available at: http://www.europarl.europa.eu/sides/getDoc. do?pubRef=-//EP//TEXT+CRE+20170201+ITEMS +DOC +XML+V0// $\mathrm{EN} \&$ language $=\mathrm{EN} \#$ creitem 12 and https://www.youtube.com/watch? $\mathrm{v}=$ Aveei10vEMY (Accessed 19 June 2017). Official transcript of European Parliament plenary, or ompte rendu in extenso (CRE): http://www.europarl.europa. eu/sides/getDoc.do?pubRef=-//EP//TEXT +CRE+20170201+ITEMS+DOC+XML $+\mathrm{V} 0 / / \mathrm{EN} \&$ language $=\mathrm{EN} \#$ creitem12 (Accessed 19 June 2017).

24 Ibid.

25 Ibid.

26 Farage, N. 2014/07/04. 'Farage on Friday: UKIP hasn't gone to Brussels to be placid and inert' vows Nigel Farage'. Daily Express. Available at: http://www.express.co.uk/ news/uk/486838/Ukip-leader-Nigel-Farage-on-EU-Parliament-Brussels (Accessed 23 June 2017).

27 2015/01/10. 'The EFF statement on the hollow recitals of the freedom charter by the ANC'. Available at: https://web.archive.org/web/20160415101933/http://effighters. org.za (Accessed 23 June 2017).

28 Ibid.

29 2017/02/01. European Parliament debate on travel restrictions following US President executive orders. Footage available at: http://www.europarl.europa.eu/sides/getDoc. do?pubRef $=-/ /$ EP//TEXT + CRE $+20170201+$ ITEMS +DOC + XML +V0// EN\&language $=\mathrm{EN} \#$ creitem 12 and https://www.youtube.com/watch? $\mathrm{v}=$ Aveeil0vEMY (Accessed 19 June 2017). Official transcript of European Parliament plenary, or ompte rendu in extenso (CRE): http://www.europarl.europa. $\mathrm{eu} /$ sides/getDoc.do?pubRef=-//EP//TEXT +CRE+20170201+ITEMS +DOC +XML $+\mathrm{V} 0 / / \mathrm{EN} \&$ language $=\mathrm{EN} \#$ creitem12 (Accessed 19 June 2017).

30 2017/02/01. Tweet ID: 8.26820435438424E+17.

31 2015/01/20. 'Economic Freedom Fighters statement on misleading claims by Zuma that he has been accountable to parliament'. Available at: https://web.archive.org/ web/20160415101933/http://effighters.org.za (Accessed 19 June 2017).

32 2017/04/06. Tweet ID: 8.49899737109024E+17.

33 2015/01/13. Tweet ID: $5.54950985832206 \mathrm{E}+17$.
34 2017/02/14. Press conference, Malema and EFF not attending SONA debate. Footage available at https://www.youtube.com/watch?v=wWREz3qMrLE (Accessed 11 Jan 2018).

35 2015/01/10. 'The EFF statement on the hollow recitals of the freedom charter by the ANC'. Available at: https://web.archive.org/web/20160415101933/http://effighters. org.za (Accessed 19 June 2017)

36 2017/02/14. 'EFF statement on the protest action against Jacob Zuma in parliament'. Available at: https://web.archive.org/web/20160415101933/http://effighters.org.za (Accessed 19 June 2017).

37 Arnott, J. 2014/07/03. 'Stitch-Ups, Backstabbing and Voters Ignored-24 h in the European Parliament'. Huffington Post. Available at: http://www.huffingtonpost.co. uk/jonathan-arnott/european-parliament_b_5553939.html (Accessed 23 June 2017).

38 2014/07/03. 'MEPs slam EU session that was over in time it takes to boil an egg'. Available at: http://www.ukip.org/ meps_slam_eu_session_that_was_over_in_time_it_takes_to_boil_an_egg (Accessed 22 June 2017)

39 2017/04/05. Tweet ID: 8.49564783091236E+17.

40 2016/06/28. European Parliament debate on the British referendum on independence from the EU. Footage available at: https://www.youtube.com/watch?v=X7le5GPJpbE and https://www.youtube.com/watch?v=tQjWV9Bhc0g (Accessed 19 June 2017). Official transcript of European Parliament plenary, or ompte rendu in extenso (CRE): http://www.europarl.europa.eu/sides/getDoc.do?pubRef=-//EP//TEXT+CRE $+20160628+\mathrm{ITEMS}+\mathrm{DOC}+\mathrm{XML}+\mathrm{V} 0 / / \mathrm{EN} \&$ language $=\mathrm{EN}$ (Accessed 19 June 2017).

$412014 / 07 / 01$. 'UKIP MEPs turn their backs on the EU flag as the EU anthem played'. Available at: https://web.archive.org/web/20140706130144/http://www.ukip.org:80/ ukip_meps_turn_their_backs_on_the_eu_flag_as_the_eu_anthem_played (Accessed 22 June 2017)

42 2015/01/10. 'The EFF statement on the hollow recitals of the freedom charter by the ANC'. Available at: https://web.archive.org/web/20160415101933/http://effighters. org.za (Accessed 19 June 2017)

43 2017/02/07. 'EFF statement on deployment of 441 SADNF members for SONA'. Available at: https://web.archive.org/web/20160415101933/http://effighters.org.za (Accessed 19 June 2017).

44 2015/02/12. State of the Nation Address, Cape Town, South Africa. Footage available at: https://www.youtube.com/watch? $\mathrm{v}=\mathrm{i} 24 \mathrm{LcoQ} 9 \mathrm{Tus}$ and https://www.youtube.com/ watch $\mathrm{v}=\mathrm{gPluIw} 3 \mathrm{uPPo}$ (Accessed 3 Feb 2017). Hansard transcript available at: http://www.politicsweb.co.za/documents/signal-jamming-and-eff-expulsion-at-sonafull-tran (Accessed 3 Feb 2017).

45 The Urban Dictionary defines 'tjatjarag' as being "over-eager and excitable in an annoying manner.” ('Urban Dictionary', n.d.).

46 2015/02/13. Tweet ID: 5.66194928469172E+17.

47 Farage, N. 2014/07/04. 'Farage on Friday: UKIP hasn't gone to Brussels to be placid and inert' vows Nigel Farage'. Daily Express. Available at: http://www.express.co.uk/ news/uk/486838/Ukip-leader-Nigel-Farage-on-EU-Parliament-Brussels (Accessed 23 June 2017).

\section{References}

Alexander JC (2011) Performance and power. Polity Press, Cambridge and Malden, MA

Alexander JC (2006) Cultural pragmatics: social performance between ritual and strategy. In: Alexander JC, Giesen B, Mast JL (eds.) Social performance: symbolic action, cultural pragmatics, and ritual. Cambridge University Press, Cambridge \& New York, p 29-91

Alexander JC (2004) Cultural pragmatics: social performance between ritual and strategy. Sociol Theory 22:527-573

Altheide DL, Snow RP (1979) Media logic. SAGE, Beverly Hills, CA

Aslanidis P (2016) Is Populism an Ideology? A Refutation and a New Perspective. Political Studies 64:88-104

Austin JL (1975) How to do things with words. Harvard University Press, Cambridge, MA

Azari JR, Smith JK (2012) Unwritten rules: informal institutions in established democracies. Perspect Polit 10:37-55

Bennett WL, Entman RM (2001) Mediated politics: communication in the future of democracy. Cambridge University Press, Cambridge

Blumler JG, Coleman S (2015) Democracy and the media-revisited. Javn Public 22:111-128

Bos L, Brants K (2014) Populist rhetoric in politics and media: a longitudinal study of the Netherlands. Eur J Commun 29:703-19

Cappella JN, Jamieson KH (1997) Spiral of cynicism: the press and the public good. Oxford University Press, New York, NY and Oxford

Carpentier N, De Cleen B (2007) Bringing discourse theory into media studies: the applicability of discourse theoretical analysis (DTA) for the study of media practises and discourses. J Lang Polit 6:265-293

Catterberg G, Moreno A (2006) The individual bases of political trust: trends in new and established democracies. Int J Public Opin Res 18:31-48 
Chadwick A (2013) The hybrid media system: politics and power. Oxford University Press, New York, NY

Charmaz K (2006) Constructing grounded theory: a practical guide through qualitative analysis. SAGE, London; Thousand Oaks, CA; New Delhi

Coleman S (2011) Representation and mediated politics: representing representation in an age of irony. In: Brants K, Voltmer K (eds.) Political communication in postmodern democracy: challenging the primacy of politics. Palgrave Macmillan, Basingstoke

Coleman S (2005) New mediation and direct representation: reconceptualizing representation in the digital age. New Media Soc 7:177-198

Coleman S, Morrison DE, Svennevig M (2008) New media and political efficacy. Int J Commun 2:771-791

Corner J (2003) Mediated persona and political culture. In: Corner J, Pels D (eds.) Media and the restyling of politics: consumerism, celebrity and cynicism. SAGE, London, Thousand Oaks and New Delhi

Couldry N (2008) Mediatization or mediation? Alternative understandings of the emergent space of digital storytelling. New Media Soc 10:373-391

Creswell J, Plano Clark V, Gutmann L, Hanson W (2003) Advanced mixed methods research designs. In: Tashakkori A, Teddlie C (eds.) Handbook of mixed methods in social \& behavioral research. SAGE, Thousand Oaks, CA

Dayan D (2013) Conquering visibility, conferring visibility: visibility seekers and media performance. Int J Commun 7:137-153

De la Torre C (ed) (2014) The promise and perils of populism: global perspectives. The University Press of Kentucky, Lexington

du Plessis AP (2015) \#SONA2015 reached 30 tweets per second in SA's first true social TV event. Memeburn. http://memeburn.com/2015/02/sona2015reach-30-tweets-per-second-in-sas-first-true-social-tv-event/. Accessed 10 Jan 2018

Enli GS (2016) Trust me, I am authentic! In: Bruns A, Enli GS, Skogerbo E, Larsson AO, Christensen C (eds.) The Routledge companion to social media and politics. Routledge, New York, NY \& Abingdon

Enli GS (2015) Mediated authenticity: how the media constructs reality. Peter Lang Publishing, New York, NY

Esser F, Stępińska A, Hopmann DN (2016) Populism and the media: cross-national findings and perspectives. In: Aalberg T, Esser F, Reinemann C, Strömbäck J, De Vreese C (eds) Populist political communication in Europe. Routledge, New York, NY \& London

Gerbaudo P (2016) From data analytics to data hermeneutics. online political discussions, digital methods and the continuing relevance of interpretive approaches. Digit Cult Soc 2:95-112

Goffman E (1959) The presentation of self in everyday life. Anchor Books, London

Gurevitch M, Coleman S, Blumler JG (2009) Political communication-old and new media relationships. Ann Am Acad Political Social Sci 625: 164-181

Halpern D, Valenzuela S, Katz JE (2017) We face, I tweet: how different social media influence political participation through collective and internal efficacy. J Comput Mediat Commun 22:320-336

Hawkins KA (2010) Venezuela's Chavismo and Populism in Comparative Perspective. Cambridge University Press, Cambridge and New York

Hay C (2013) Why we hate politics. John Wiley \& Sons, Cambridge and Malden, MA

Healey K (2010) The pastor in the basement: discourses of authenticity in the networked public sphere. Symb Interact 33:526-551

Hepp A, Krotz F (eds) (2014) Mediatized worlds: culture and society in a media age. Palgrave Macmillan UK, Basingstoke

Jägers J, Walgrave S (2007) Populism as political communication style: an empirical study of political parties' discourse in Belgium Eur J Political Res 40:319-345

Krämer B (2017) Populist online practices: the function of the Internet in rightwing populism. Inf Commun Soc 20:1293-1309

Krämer B (2014) Media populism: a conceptual clarification and some theses on its effects. Commun Theory 24:42-60

Kriesi H (2014) The populist challenge. West Eur Polit 37:361-78

Larsson A O (2015) Comparing to prepare: suggesting ways to study social media today -and tomorrow. Soc Media Soc. https://doi.org/10.1177/2056305115578680

Lievrouw LA (2014) Materiality and media in communication and technology studies. In: Gillespie T, Boczkowski PJ, Foot KA (eds.) Media technologies: essays on communication, materiality, and society. MIT Press, Cambridge, MA

Livingstone S (2009) On the mediation of everything: ICA Presidential address 2008. J Commun 59:1-18

Louden A, McCauliff K (2004) The 'authentic candidate': extending candidate image assessment. In: Hacker KL (ed) Presidential candidate images. Rowman \& Littlefield Publishers, Lanham, p 85-103

Mazzoleni G, Stewart J, Horsfield B (eds.) (2003) The media and neo-populism: a contemporary comparative analysis. Praeger, Westport
Meyrowitz J (1986) No sense of place: the impact of electronic media on social behavior. Oxford University Press, New York, NY \& Oxford

Moffitt B (2016) The global rise of populism: performance, political style, and representation. Stanford University Press, Stanford, CA

Mudde C (2004) The populist zeitgeist. Gov Oppos 39:542-563

Mudde C, Rovira Kaltwasser C (2012) Populism in Europe and the Americas: threat or corrective for democracy? Cambridge University Press, New York, NY

Norris P (2001) Political communications and democratic politics. In: Bartle J, Griffiths D (eds.) Political communications transformed: from Morrison to Mandelson. Palgrave, Basingstoke \& New York, NY

Nyhan B (2017) Norms matter. POLITICO Magazine. https://www.politico.com/ magazine/story/2017/09/05/why-norms-matter-politics-trump-215535 Accessed 11 Jan 2018.

Parry K (2015) Visibility and visualities: 'ways of seeing' politics in the digital media environment. In: Coleman S, Freelon D (eds.) Handbook of digital politics. Edgar Elgar Publishing, Cheltenham, p 417-32

Pels D (2003) Aesthetic representation and political style: re-balancing identity and difference in media democracy. In: Corner J, Pels D (eds.) Media and the restyling of politics: consumerism, celebrity and cynicism. SAGE, London, Thousand Oaks and New Delhi, p 67-84

Phillips LJ, Jørgensen MW (2002) Discourse analysis as theory and method. SAGE, London, Thousand Oaks and New Delhi

Silverstone R (2005) The sociology of mediation and communication. In: Calhoun C, Rojek C, Turner B (eds) The SAGE handbook of sociology. SAGE Thousand Oaks, pp 188-207

Sorensen L (2017) Populism in communications perspective: concepts, issues, evidence. In: Heinisch R, Holtz-Bacha C, Mazzoleni O (eds.) Political populism: a handbook. Nomos, Baden-Baden

Spary C (2010) Disrupting rituals of debate in the indian parliament. J Legis Stud $16: 338-351$

Stanyer J (2007) Modern political communications: mediated politics in uncertain terms. Polity, Cambridge and Malden

Stavrakakis Y, Andreadis I, Katsambekis G (2016) A new populism index at work: identifying populist candidates and parties in the contemporary Greek context. Eur Politics and Soc 0:1-19. https://doi.org/10.1080/ 23745118.2016.1261434

Strömbäck J (2008) Four phases of mediatization: an analysis of the mediatization of politics. Press/Polit 13:228-246

Taylor C (1992) The ethics of authenticity. Harvard University Press, Cambridge

Thompson JB (2005) The new visibility. Theory Cult Soc 22:31-51

Thompson JB (1995) The media and modernity: a social theory of the media. Polity, Cambridge

Trilling L (1972) Sincerity and authenticity. Harvard University Press, Cambridge, MA \& London

Van Dijk TA (2016) Ideology. In: Mazzoleni G (ed) The international encyclopedia of political communication. John Wiley \& Sons, Hoboken, NJ, p 1-11

\section{Data availability}

The datasets generated and analysed during the current study are not publicly available due to being part of an ongoing PhD study funded by the University of Leeds but are available from the corresponding author on reasonable request.

Mecodify, the tool used for the extraction and visualisation of tweets, is open source. See official web page http://mecodem.eu/mecodify and documentation in the GitHub repository at https://github.com/wsaqaf/mecodify/blob/master/manual.md.

\section{Acknowledgements}

The South African part of this study was conducted in the context of the project 'Media Conflict and Democratisation' (www.mecodem.eu), led by Katrin Voltmer, University of Leeds (UK). The project received funding from the European Union's Seventh Framework Programme for research, technological development and demonstration under grant agreement no 613370. I am grateful to Prof. Katrin Voltmer, Dr Katy Parry, Prof. Stephen Coleman and Prof. Jay Blumler for their comments on an earlier draft.

\section{Additional information}

Competing interests: The author declares no competing interests.

Reprints and permission information is available online at http://www.nature.com/ reprints

Publisher's note: Springer Nature remains neutral with regard to jurisdictional claims in published maps and institutional affiliations. 
(c) (i) Open Access This article is licensed under a Creative Commons Attribution 4.0 International License, which permits use, sharing, adaptation, distribution and reproduction in any medium or format, as long as you give appropriate credit to the original author(s) and the source, provide a link to the Creative Commons license, and indicate if changes were made. The images or other third party material in this article are included in the article's Creative Commons license, unless indicated otherwise in a credit line to the material. If material is not included in the article's Creative Commons license and your intended use is not permitted by statutory regulation or exceeds the permitted use, you will need to obtain permission directly from the copyright holder. To view a copy of this license, visit http://creativecommons.org/ licenses/by/4.0/.

(c) The Author(s) 2018 